\title{
The First Gastronomy Culture in World History on Turkish Land Çatalhöyük
}

\author{
Ali Batu* \\ Food, Nutrition and Gastronomy Science, Turkey
}

Submission: August 16, 2018; Published: August 29, 2018

*Corresponding author: Ali Batu, Food, Nutrition and Gastronomy Science, Turkey, Email: alibatu42@gmail.com

Keywords: Human skull; Funerary rities; Selection; Conservation; Paleolithic, Mesolithic; Neolithic; Sprinkled; Columbella rustic; Gyraulus; Lithoglypus; Anthropophagy; Fertility; Lake basin; Death; Skeleton; Inhabitants

Mini Review

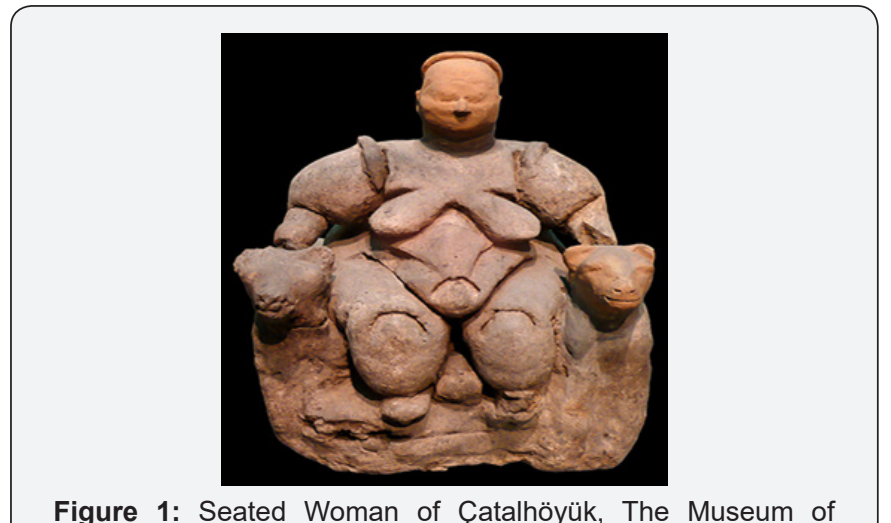

Anatolian Civilizations, Ankara, Turkey.

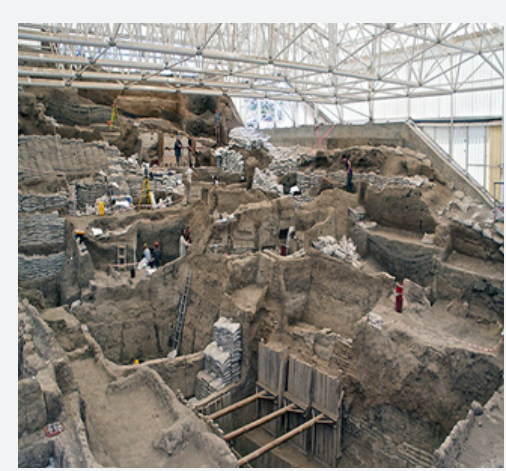

Figure 2: The Neolithic settlement Çatalhöyük, located in the Çumra district of Konya.

The excavations at Çatalhöyük keep the lights on human history. Situated on the UNESCO World Heritage List, Çatalhoyuk is a Neolithic settlement. Çatalhoyuk is one of the most exciting excavation areas in the world archeological circles. It is a very large settlement of Neolithic and Chalcolithic Age, which was established 9.400 years ago today in the Çumra county of Konya in Central Anatolia. It is made up of two tumuli side by side in the east and west directions. The settlement called Çatalhoyuk-East in the east is located in the Neolithic Age, The western mound, called Çatalhoyuk-West), was planted in the Chalcolithic Age. It is $52 \mathrm{~km}$ away from Konya Province, approximately $136 \mathrm{~km}$ away from Hasandağı, It lies $11 \mathrm{~km}$ north of the Çumra District, on the grounds dominated by the Konya Plain. Eastern settlement forms a settlement unit reaching 20 meters high from the rubble during polished stone age. There is also a small settlement to the west and a Byzantine settlement to the east a few hundred meters. The mounds have been around for 2,000 years (Figures 1-4). It is particularly striking with its extensive neolithic settlement, its population, and its strong tradition of art and culture [1].
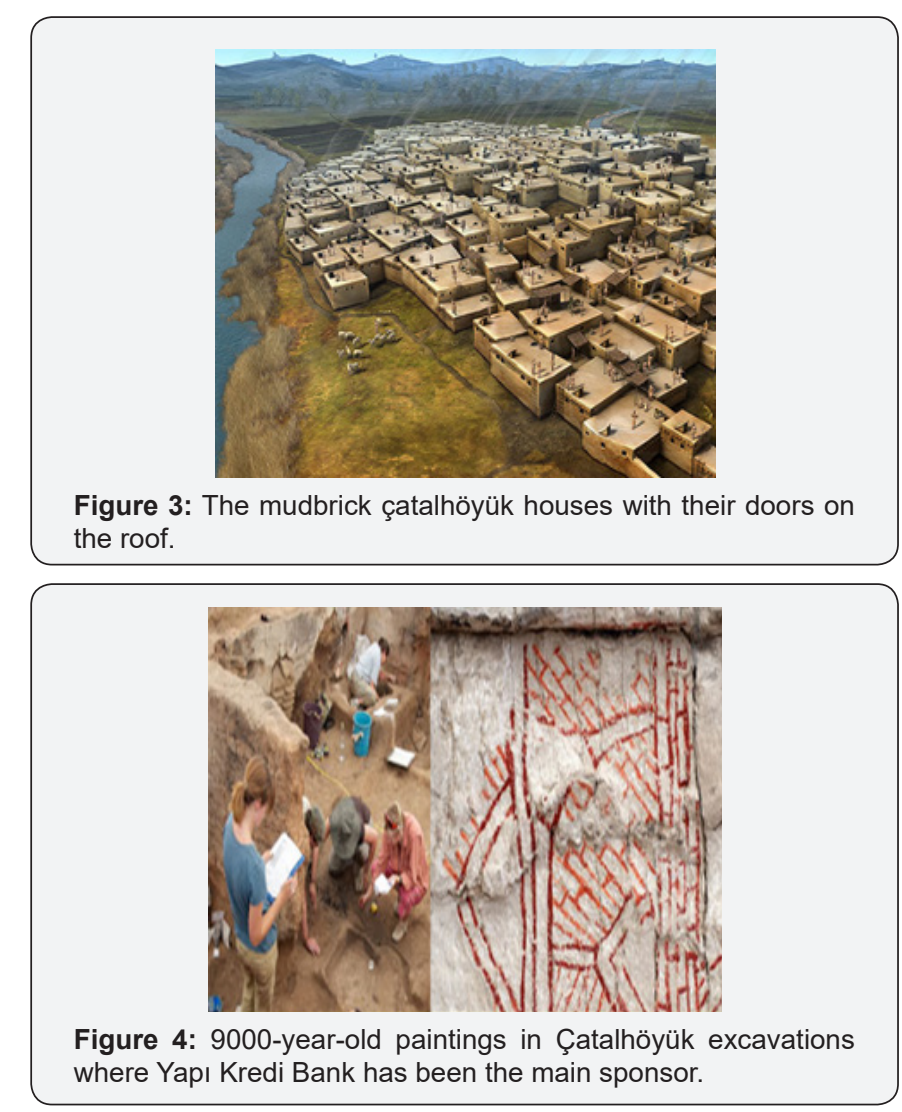
Çatalhoyuk sheds light on human history with 9 thousand years of history. Çatalhoyuk, where the 8,000 people lived together in the Neolithic period, is considered to be one of the first settlements of human beings on earth. It was discovered in the 1960s by British archaeologist James Mellaart and his team. People in Çatalhoyuk, 9 thousand years ago; they lived in mud-brick houses adjacent to each other, entered from roof. In this excavation study, various topics such as social structure, nutrition and clothing patterns of people are being investigated. Çatalhoyuk, a Neolithic settlement, is one of the most exciting excavation sites in the world archeological circles. Excavations at Çatalhoyuk by British scientist "Prof. Dr. Ian Hodder" made a big curiosity in world about details of the people who lived 9 thousand years ago in Çatalhoyuk [1].

\section{Wheat was Grown for the First Time}

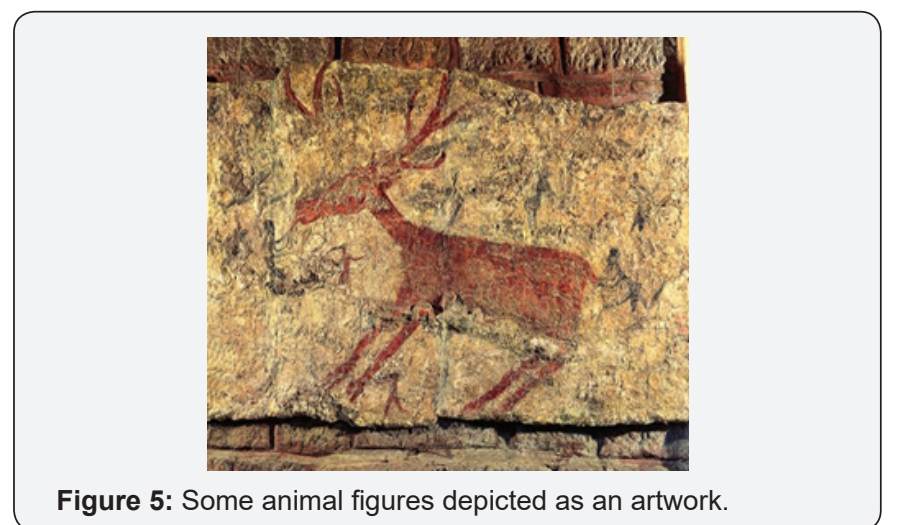

Çatalhoyuk, the place where mankind first began to harvest from the soil in the Middle East and Mediterranean canteen, comes to the forefront with people starting to grow wheat and wall paintings and oxen heads drawn in the direction of their religious beliefs. The findings of Çatalhoyuk, which aims to shed light on the adventures of human beings in the world (Figure 5), reveal every new cloud of human nutrition, bones, and genetic characteristics to the unknowns of today's modern people [2].

\section{People were Shorter}

It is said that people are shorter than 1.70 meters and shorter than today's people, but they are much stronger than today's people, at Çatalhoyuk where the pre-existing settlement where people 9,000 years ago had just started their agricultural activities.

\section{Dead People Buried at Home}

Today, it is known that there were many tombs and skeletons in the houses during the excavations, and that people in the settlements enter the houses through the holes in the roof and take advantage of the house in the house to warm up and cook. The earliest evidence of the leopards living in Anatolia is of interest because of the leopard motifs that decorate the walls of the houses in Çatalhöyük. Çatalhöyük was introduced to the world and is the most important center of the Neolithic period [1].

\section{Visitor Density Increased with UNESCO}

Significant findings were found in the 25-year work program of excavations that began in 1993 under the chairmanship of "Prof. Dr. Ian Hodder" from Cambridge University. Initially, the studies started with the University of Cambridge and then continued with the London and Stanford universities (Figures 6 \& 7). "The excavations started at Çatalhöyük in 1960 are continuing at the site where new discoveries will be brought to light and removed during this time. Çatalhöyük was taken to the World Heritage List by UNESCO in 2012. After that, every year a large number of visitors come to visit to the excavation center and get information about the finds here [1].
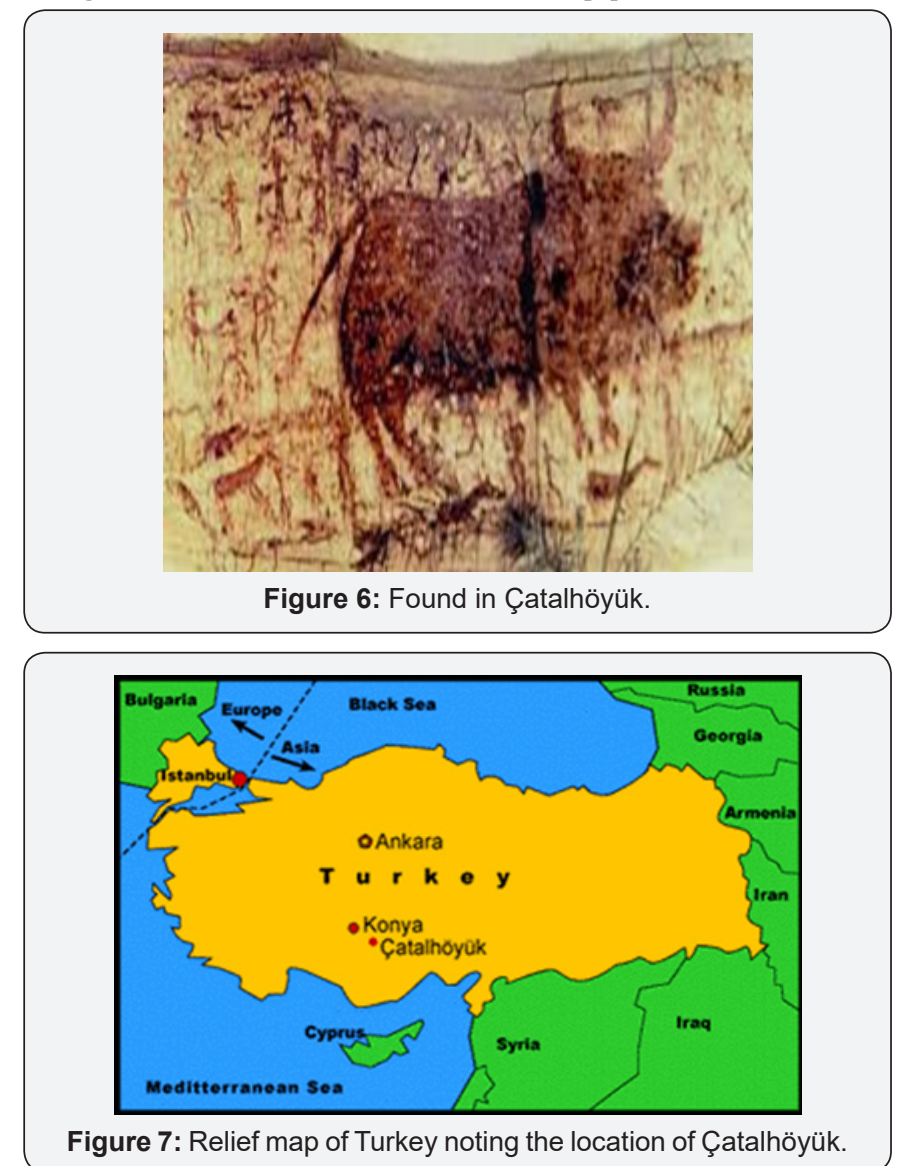

One of the most important archaeological sites of Anatolia, Çatalhöyük is supported by Yapı Kredi Bank. The excavations have found pictures of this past 9,000 years old. These paintings, which have very important clues to understand the history of Anatolian civilization, were discovered in 2007. It is considered to be the most important finding discovered after the pottery of 6700 years.

Those living in Çatalhöyük covered their walls with white clay to prevent their houses from being covered with heat. For this reason, each of these layers was carefully removed one by one during excavation. The panel under the castle was painted with the wall, and this red paint seemed to be still fresh. Another exciting finding this year was that a calf's head was painted red and hung on a carving in another house. This animal head stood 
on the platform on which 9 graves were located. In the houses, there are various pictures often found in the areas where the dead are buried. These paintings and objects are thought to be a way for people living at that time to communicate with the deceased [3].

\section{First Gastronomy for Human Being}

From the nutritional point of view, the presence of fossils of charcoal, grain, seed, wild fruits and plant nests; the presence of cookers, storage tanks, food processing tools and crop deposits in adjacent houses; There are also a large number of wooden bowls, baskets made of soil pots and plants, availability of goods; show that these products are used, processed, kept for long to consume and can be produced in the following year. The plants used for the food consisted of bread wheat, barley, peas, vetch, wild almond, oak, oak and hedgehog. In addition, it can be said that the study data were used in the grasses such as rye, chickpea, lentil, fig, plum, sumac, blackberry and hibiscus, labada, geven, hasirotu, black pepper [4].

The Anatolian Peninsula, which acts as a bridge between Asia and Europe, has been a region preferred by people throughout history due to its location, geographical features and rich natural resources, despite its rugged topographical structure. World history is divided into various periods such as Palaeolithic, Mesolithic, Neolithic and following Bronze and Iron Ages. These ages Considering mankind's historical oldest seen in Anatolia Old Stone Age or the common name in Turkey Chipped Stone Age given name dates back to the early Palaeolithic $[5,6]$. The earliest settlement in Anatolia is mentioned in the Lower Paleolithic Age as the Yarım Burgaz Cave near Istanbul's Küçük Çekmece Cave and the Karain Cave, the most important settlement dated immediately after the Halburg Burgaz Cave. Palaeolithic people continued to live in a convergent lifestyle by searching for new food sources in parallel with the changes in the climate they were in, and therefore the environment, in small groups [6].

The Neolithic Age, which forms the basis of the social and economic level of the $21^{\text {st }}$ century, is recognized as the most important stage in the cultural evolution and development of mankind. In this period, there have been fundamental changes in

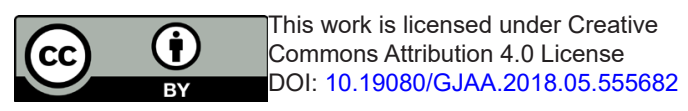

the way of life and livelihood of human beings. These fundamental changes are the transition from people to permanent settlements in temporary natural shelters, to production from hunting and gathering, that is to agriculture and animal husbandry [7]. Since the emergence of village life based on food production constitutes the foundations of contemporary civilizations, the Neolithic Age has a special precaution. This new way of life, which emerged in some parts of Anatolia and the Near East, remained in this region until it completed its development (about 4000 years). It was later influenced in Europe and contributed to the formation of European civilization [4,8].

This summer, 122 people from 22 countries came to join the Turkish team to take part in the Çatalhöyük excavations carried out in the main sponsorship of Yapı Kredi Bank. The other main sponsor, Boeing, is also supported by Shell in Çatalhöyük excavations. Chatalhoyuk is on the UNESCO Temporary List of World Heritage Sites. To enter the main list, a short time ago, an attempt was initiated by Turkey's Culture and Tourism Ministry [1].

\section{References}

1. Konyayenigun (2018) Konya New Day (Konya Yeni Gün).

2. Haberler com (2018) First Resident and Equal Life Wife: Çatalhöyük Konya (İlk Yerleşik ve Eşit Yaşamın Tanığı: Çatalhöyük - Konya).

3. Kulturportali (2018) Neolithic city of Çatalhoyuk-Konya.(Çatalhöyük Neolitik Kenti-Konya).

4. Aksoy Mve Çetin K (2018) Çatalhöyük Mutfak Yapıları ve AraçGereçlerinin 21. Yüzyıl Mutfak Kültürüne Yansımaları1 (The $21^{\text {st }}$ Century Cuisine Cultural Reflections on Çatalhöyük Cuisine Construction and Equipment). Journal of Tourism and Gastronomy Studies 6(1): 125-141.

5. Sevin V (2013) Anadolu Arkeolojisi: Başlangıçtan Persler'e Kadar. Der Yayınları, İstanbul.

6. Yalçınkaya I (2000) İnsanlık Tarihinden Bir Kesit: Paleolitik Çă̆, Antropoloji ve Yaşlılık, Prof. Dr. Vedia Emiroğlu'na Armağan, 15-30.

7. Özdoğan M (2007) Neolitik Dönem Günümüz Uygarlığının Temel Tașları. 12000 Yıl ÖnceUygarlığın Anadolu'dan Avrupa'ya Yolculuğunun Başlangıcı Neolitik Dönem (Editör:Nezih Başgelen), Yapı Kredi Yayınları, Mas Matbaacılık, İstanbul p. 9-21.

8. Güldemir O (2009) Çatalhoyuk Nutrition Culture -Plant (Çatalhöyük Beslenme Kültürü (Bitki).

\section{Your next submission with Juniper Publishers will reach you the below assets}

- Quality Editorial service

- Swift Peer Review

- Reprints availability

- E-prints Service

- Manuscript Podcast for convenient understanding

- Global attainment for your research

- Manuscript accessibility in different formats

( Pdf, E-pub, Full Text, Audio)

- Unceasing customer service

Track the below URL for one-step submission https://juniperpublishers.com/online-submission.php 